\title{
White and orange fleshed-sweet potato starches modified by autoclave
}

\author{
Amidos de batata-dloce de polpas branca e laranja modificados por autoclave \\ Almidones de boniato de pulpa blanca y naranja modificados por autoclave
}

Received: 12/31/2020 | Reviewed: 01/02/2021 | Accept: 01/02/2021 | Published: 01/05/2021

Giselle de Lima Paixão e Silva

ORCID: https://orcid.org/0000-0001-9838-5663 Federal University of Goiás, Brazil E-mail: xpaixao@hotmail.com

Juliana Aparecida Correia Bento ORCID: https://orcid.org/0000-0001-9015-9426 Federal University of Goiás, Brazil E-mail: julianaap.ufg@gmail.com

Luiz Artur Mendes Bataus

ORCID: https://orcid.org/0000-0002-5437-6762 Federal University of Goiás, Brazil E-mail: bataus@ufg.br

Manoel Soares Soares Júnior

ORCID: https://orcid.org/0000-0001-8728-4592 Federal University of Goiás, Brazil E-mail: manoel@ufg.br

Márcio Caliari

ORCID: https://orcid.org/0000-0002-0877-8250 Federal University of Goiás, Brazil E-mail: macaliari@ufg.br

Menandes Alves de Souza Neto ORCID: https://orcid.org/0000-0001-5560-6884 Federal University of Goiás, Brazil E-mail: menandesneto@gmail.com

Karen Carvalho Ferreira

ORCID: https://orcid.org/0000-0002-2664-1899 Federal University of Goiás, Brazil

E-mail: karencarvalho1@ hotmail.com

Ana Lázara Matos de Oliveira

ORCID: https://orcid.org/0000-0003-3767-3885 Federal University of Lavras, Brazil E-mail: analazara.eng@gmail.com

Jhonathan Raphael Andrade

ORCID: https://orcid.org/0000-0002-8656-854X

State University of Ponta Grossa, Brazil

E-mail: jhonathandrade@gmail.com

\begin{abstract}
The objective of this research, using a Composite Central Rotational Design, was to evaluate whether the moisture and exposure time to a temperature of $121{ }^{\circ} \mathrm{C}$ and pressure of $1.1 \mathrm{kgf.} \mathrm{cm}^{2}$ in an autoclave would be capable of modifying the morphological, thermal, functional and pasting properties of orange (OSP) and white (WSP)-fleshed sweet potato starches. The modification increased: the WAI at $60^{\circ} \mathrm{C}$ of WSP starch and of WSI at $60^{\circ} \mathrm{C}$ of OSP starch, the setback of WSP starch, the final viscosity of OSP starch and enthalpy for both, besides reduced the breakdown of OSP starch. The micrographs of modified starches showed cracks and on the surface of the granules, and pregelatinization of OSP starch, confirming that the moisture and exposure time affected their morphological, thermal, functional and pasting properties. Therefore, due the promising use the authors suggest future researches with WSP and OSP autoclaved starches to test technological applications.
\end{abstract}

Keywords: Ipomoea batatas L; RVA; DSC; Water solubility and absorption; Scanning electron microscopy.

\section{Resumo}

O objetivo desta pesquisa, utilizando um Delineamento Central Composto Rotacional, foi avaliar se a umidade e o tempo de exposição a uma temperatura de $121^{\circ} \mathrm{C}$ e pressão de $1.1 \mathrm{kgf} . \mathrm{cm} 2$ em autoclave seriam capazes de modificar as propriedades morfológicas, térmicas, funcionais e de pasta dos Amidos de Batata Doce de polpas de cor Laranja (ABDL) e Branca (ABDB). A modificação demonstrou aumentar: a absorção a $60^{\circ} \mathrm{C}$ do amido ABDB e a solubilidade a $60^{\circ} \mathrm{C}$ do $\mathrm{ABDL}$, o setback do $\mathrm{ABDB}$, a viscosidade final do $\mathrm{ABDL}$ e a entalpia para ambos, além de reduzir o breakdown do ABDL. As micrografias dos amidos modificados mostraram rachaduras na superfície dos grânulos e pré-gelatinização do ABDL, confirmando que a umidade e o tempo de exposição afetaram suas 
propriedades morfológicas, térmicas, funcionais e de pasta. Portanto, devido ao uso promissor, os autores sugerem pesquisas futuras com ABDL e ABDBR autoclavados para testar aplicações tecnológicas.

Palavras-chave: Ipomoea batatas L; RVA; DSC; Solubilidade e absorção em água; Microscopia eletrônica de varredura.

\section{Resumen}

El objetivo de esta investigación, utilizando un Diseño Rotacional Central Compuesto, fue evaluar si la humedad y el tiempo de exposición a una temperatura de $121^{\circ} \mathrm{C}$ y presión de $1.1 \mathrm{kgf}$. cm2 en autoclave sería capaz de modificar las propiedades morfológicas, térmicas, funcionales y de pegado de los almidones de batata con pulpa naranja (ABDL) y blanca (ABDB). La modificación aumentó: el absorcíon a $60^{\circ} \mathrm{C}$ de $\mathrm{ABDB}$ y de solubilidad a $60^{\circ} \mathrm{C}$ de ABDL, el setback del ABDB, la viscosidad final del ABDL y la entalpía para ambos, además de reducir la breakdown del ABDL. Las micrografías de almidones modificados mostraron grietas y en la superficie de los gránulos, y pregelatinización del ABDL, confirmando que la humedad y el tiempo de exposición afectaron sus propiedades morfológicas, térmicas, funcionales y de pegado. Por lo tanto, debido al uso prometedor, los autores sugieren futuras investigaciones con ABDL e ABDB esterilizados en autoclave para probar aplicaciones tecnológicas.

Palabras clave: Ipomoea batatas L; RVA; DSC; Solubilidad y absorción en agua; Microscopía electrónica de barrido.

\section{Introduction}

The sweet potato (Ipomoea batatas L.) starch is being widely used in the food industry (Zuo, Hébraud, Hemar, \& Ashokkumar, 2012). The starches extracted from the colored flesh of the various sweet potato cultivars have similar physicochemical properties but different pasting and thermal properties (Guo, Liu, Lian, Li, \& Wu, 2014; Lee \& Lee, 2017).

Starch granules exhibit distinctive morphologies and technological properties that are affected by factors such as: color, root genotype, environmental conditions and the soil type where they were grown (Narpinder, Amritpal, Khetan, \& Rajarathnam, 2013). Colored sweet potato starches extracted from sweet potatoes of different flesh colors, may have heterogeneous granules sizes and shapes and different crystallinity patterns. The viscoamylographic profile of native white and orange-fleshed sweet potato starches in previous studies showed good thermal stability, being indicated for the potential use in foods processed at high temperatures, such as sauces and snacks (Paixão \& Silva et al., 2020).

Deka and Sit (2016) stated that the use of native starches in food processing has limitations such as the formation of a weak, cohesive, and elastic paste when heated; and the formation of an unwanted gel when refrigerated or stored. Due to these limitations, the functional properties of these starches can be improved by modifications using physical, chemical, or enzymatic methods.

The physical modification of starch for application in food is one of the most viable ways, since it is associated with environmental preservation and sustainability and does not produce residues, to the contrary of chemical modifications. In addition, changes in the nutritional properties of starches modified by chemical means, which could affect human health, have been poorly studied (Zhu, 2015). Thus, the physical modifications of starch are more attractive since they are considered to be natural and safe for the consumer (Zuo et al., 2012).

Among the methods most used in the physical modification of sweet potato starch are heat-moisture treatment (HTM) (Huang, Zhou, Jin, Xu, \& Chen, 2016; Jyothi, Sajeev, \& Sreekumar, 2010; Trung, Ngoc, Hoa, Tien, \& Hung, 2017) and high hydrostatic pressure (HPP) (Carballo Pérez, Mu, Zhang, \& Ji, 2018; Song, Choi, Kim, Kim, \& Baik, 2015). HMT is a modification that involves low moisture levels, usually in a restricted range of 10-30\%, and heating at high temperatures (90$120 \circ \mathrm{C}$ ) for a period of time ranging from $15 \mathrm{~min}$ to $16 \mathrm{~h}$ (Zavareze \& Dias, 2011). In HPP different combinations of pressure (above $100 \mathrm{MPa}$ ) and temperature can be used to achieve desired effect on texture, colour and flavour of foods (Carballo Pérez et al., 2018).

However, there are few studies with the physical modification of sweet potato starch by autoclaving at low pressures $\left(1.1 \mathrm{kgf} . \mathrm{cm}^{2}, 121^{\circ} \mathrm{C}\right.$ ) with different exposure times and moistures (Akanbi, Kadiri, \& Gbadamosi, 2019; Babu \& Parimalavalli, 
2013). The physical modification of starch in an autoclave is an advantageous type of modification, particularly favorable for application in foods, resulting in new functional properties (Babu \& Parimalavalli, 2014). Previous studies using autoclave reported changes in the granular structure of arrowroot starch (Astuti, Widaningrum, Asiah, Setyowati, \& Fitriawati, 2018), in the texture of rice starch ( $\mathrm{Li}, \mathrm{Yu}, \mathrm{Yu}, \mathrm{Li}, \&$ Gilbert, 2019; Song et al., 2015) and in the thermal stability of oat starch (Shah, Masoodi, Gani, \& Ashwar, 2016).

Thus, in order to enhance the application of orange and white-fleshed sweet potato starch, the objective of this research was to evaluate whether the moisture and time of exposure to a temperature of $121{ }^{\circ} \mathrm{C}$ with a pressure of $1.1 \mathrm{kgf} . \mathrm{cm}^{2}$ in an autoclave would be capable of modifying the morphological, thermal, functional and pasting properties of white (WSP) and orange (OSP)- fleshed sweet potato starches.

\section{Methodology}

The methodology used in this article was experimental, explanatory and quantitative, according to the classification described by Pereira, Shitsuka, Parreira, and Shitsuka (2018).

\subsection{Material and starch extraction}

Samples consisting of $20 \mathrm{Kg}$ each of white (common variety) and orange (BRS Amélia variety) fleshed sweet potatoes (Ipomoea batatas L.) were obtained from a farm located at a latitude of $16^{\circ} 58^{\prime} 11.46^{\prime \prime}$, longitude of 49 $11^{\prime} 12.206^{\prime \prime}$ and altitude of $830 \mathrm{~m}$. The sweet potatoes were transported in polyethylene bags to the laboratory and immediately processed. The starch was extracted as described by Bento et al. (2019) with modifications: the roots were washed, peeled, cut into $4 \mathrm{~cm}$ slices, immersed in sodium metabisulfite solution $\left(5 \mathrm{~g} \mathrm{~L}^{-1}\right.$ of water) for $15 \mathrm{~min}$., and then ground with water in an industrial blender for 2 min. with a 2: 1 ratio (distilled water: sweet potato). The mass obtained was filtered through 35 and 400 mesh sieves, decanted for $4 \mathrm{~h}$, and drained. The starch was resuspended in water, decanted again for $3 \mathrm{~h}$, drained, dried in a forced air oven at $40^{\circ} \mathrm{C}$ for $48 \mathrm{~h}$, reduced to a powder using a pestle and mortar, and finally sieved through a 60-mesh sieve.

\subsection{Autoclave modification}

Autoclave modification of OSP and WSP starches was performed according to a methodology proposed by Abraham (1993) with adaptations. $30 \mathrm{~g}$ of the starches were placed in autoclavable polyethylene bottles and adjusted to the desired moisture by adding distilled water. After kept 24 hours the moisture content of samples was verified by infrared balance (Ohaus MB23, Parsippany, New Jersey). $2^{2}$ Factorial Central Compound Rotational designs (CCRD) with 4 axial experiments and 3 repetitions at the central point, totaling 11 experiments were used, one for each type of sweet potato, each with two variables and five levels: heat treatment exposure time $(15 ; 21.54 ; 37.50 ; 53.46$ and 60 min.) and moisture content (20; 22.91 ; 30; 37.09 and 40\%). A vertical autoclave (Phoenix Scientific Equipment mod-AV50, Araraquara, Brazil), with a fixed temperature and pressure $\left(121^{\circ} \mathrm{C}\right.$ and $1.1 \mathrm{kgf} \mathrm{cm}^{2}$, respectively) was used to carry out the changes in the OSP and WSP starches. After autoclaving, the modified starches were dried in a forced air oven at $40{ }^{\circ} \mathrm{C}$ for $24 \mathrm{~h}$. The lumps formed were reduced to powder with the aid of a mini-grinder and then sieved through a 60-mesh sieve.

\subsection{Gel transparency or transmittance}

The transparency of the gel was determined according to Zheng et al. (2013), whereby $0.1 \mathrm{~g}$ portions of the samples were added to $10 \mathrm{ml}$ of water ( $1 \%$ suspension) in a test tube and heated in a water bath at $95^{\circ} \mathrm{C}$ for 30 min. with agitation. They were then cooled for $15 \mathrm{~min}$. to room temperature, and the transmittance determined in a spectrophotometer (Bel 107 Photonic, SP2000UV, Piracicaba, Brazil) at $620 \mathrm{~nm}$, using water as the blank. 


\subsection{Water solubility and swelling power index}

The water solubility and absorption indexes (WSI and WAI) were determined as described by Bento et al. (2019) at temperatures of $60^{\circ} \mathrm{C}, 70{ }^{\circ} \mathrm{C}$ and $80^{\circ} \mathrm{C}$. The result of WAI was expressed in g gel (g dry matter) ${ }^{-1}$, and the WSI expressed in $\%$.

\subsection{Differential scanning calorimetry (DSC)}

The thermal properties were determined in a Differential Scanning Calorimeter - DSC (TA Instruments, Q20, Newcastle, UK), as described by Bento et al. (2019). The gelatinization enthalpy $(\Delta \mathrm{H})$ and the onset (To), the peak (Tp) and the end of gelatinization $(\mathrm{Tc})$ temperatures were obtained from the thermogram produced by the calorimeter.

\subsection{Pasting properties}

The pasting properties were evaluated in a Rapid Visco Analyzer (RVA) (Perten, 131 RVA 4500, Huddinge, Sweden) according to the criterion adopted by Bento et al. (2020). The pasting properties evaluated were: peak viscosity, final viscosity, breakdown viscosity and the tendency to retrograde (setback), all expressed in $\mathrm{cP}$ and the pasting temperature in ${ }^{\circ} \mathrm{C}$.

\subsection{Gel hardness}

After completing the analysis of the pasting properties, the samples were kept under refrigeration overnight, and the gel strength at $25^{\circ} \mathrm{C}$ subsequently determined in a texturometer (TA HD Plus Stable Micro Systems, Surrey, England), using a $20 \mathrm{~mm}$ cylindrical probe, $8 \mathrm{~mm}$ penetration depth, 10 g.f contact force and test, pre-test and post-test speeds of $0.5,1.0$ and $10.0 \mathrm{~mm} \mathrm{~s}^{-1}$, respectively (Wani, Sogi, Wani, Gill, \& Shivhare, 2010).

\subsection{Scanning electron microscopy (SEM)}

The granule morphology was analyzed in a scanning electron microscope (Jeol, JSM - 6610, Tokyo, Japan) as described by Bento et al. (2019). The photographs were produced in triplicate, with magnifications of 1500x. The particle dimensions were determined using the IMAGE software (Schneider, Rasband, \& Eliceiri, 2012).

\subsection{Statistical analysis}

All data were obtained in triplicate and evaluated by response surface methodology and multiple variance analysis, and models were adjusted and visualized by means of response surface graphs (Statsoft, Statistic 10.0, Tulsa, USA). Models were also validated in three-replicate assays using the central point of the first design.

\section{Results and Discussion}

Table 1 shows the significant adjusted models $(\mathrm{p}<0.05)$ with non-significant lack of fit $(\mathrm{p}>0.05)$ and the determination coefficients above $70 \%$ of WAI (at 60 and $70^{\circ} \mathrm{C}$ ) and WSI (at 60,70 and $80^{\circ} \mathrm{C}$ ); breakdown, final viscosity and setback; gelatinization enthalpy obtained from the DSC; and the hardness and transparency of the gels, from OSP and WSP autoclaved starches. In the validation test, it was found that all the models were predictive (with an accuracy level greater than $95 \%)($ error $<5 \%)$ with the exception of the gelatinization enthalpy of OSP starch autoclaved (with compatibility of $90.47 \%)$. 
Table 1. Adjusted Models for WAI, WSI, pasting properties (breakdown, final viscosity and setback), gelatinization enthalpy measurement of DSC, gel hardness and transparency of OSP and WSP autoclaved starches. X1 = time (min); X2 = moisture $(\%)$.

\begin{tabular}{|c|c|c|c|c|}
\hline Characteristic & Model* & $\mathrm{p}$ & $\mathrm{R}^{2}$ & $\mathrm{LF}$ \\
\hline WAI o at $70^{\circ} \mathrm{C}^{1}$ & $\mathrm{y}=6.70+1.27 \mathrm{x}_{2}+0.71 \mathrm{x}_{2}^{2}$ & 0.016 & 0.86 & $0.29^{\mathrm{ns}}$ \\
\hline WAI $w$ at $60{ }^{\circ} \mathrm{C}^{1}$ & $\mathrm{y}=4.16+0.59 \mathrm{x}_{1}^{2}+1.85 \mathrm{x}_{2}+1.12 \mathrm{x}_{2}^{2}$ & 0.011 & 0.97 & $0.19^{\text {ns }}$ \\
\hline WAI $w$ at $70{ }^{\circ} \mathrm{C}^{1}$ & $\mathrm{y}=4.29+2.16 \mathrm{x}_{2}+1.68 \mathrm{x}_{2}^{2}$ & 0.006 & 0.85 & $0.11^{\mathrm{ns}}$ \\
\hline WSI o at $60^{\circ} \mathrm{C}^{2}$ & $\mathrm{y}=1.48+0.38 \mathrm{x}_{1}+1.17 \mathrm{x}_{2}+0.59 \mathrm{x}_{2}^{2}+0.55 \mathrm{x}_{1} \mathrm{x}_{2}$ & 0.001 & 0.98 & $0.09^{\mathrm{ns}}$ \\
\hline WSI o at $80^{\circ} \mathrm{C}^{2}$ & $\mathrm{y}=4.59+1.05 \mathrm{x}_{2}-0.797 \mathrm{x}_{2}^{2}$ & 0.020 & 0.77 & $0.17^{\mathrm{ns}}$ \\
\hline WSI $w$ at $70^{\circ} \mathrm{C}^{2}$ & $\mathrm{y}=0.95+0.98 \mathrm{x}_{2}+0.91 \mathrm{x}_{2}^{2}$ & 0.024 & 0.71 & $0.07^{\mathrm{ns}}$ \\
\hline Breakdown o ${ }^{3}$ & $\mathrm{y}=-0.25-0.16 \mathrm{x}_{1}-0.03 \mathrm{x}_{1}^{2}+0.04 \mathrm{x}_{2}-0.015 \mathrm{x}_{2}^{2}-0.03 \mathrm{x}_{1} \mathrm{x}_{2}$ & 0.006 & 0.99 & $0.30^{\mathrm{ns}}$ \\
\hline Final viscosity o ${ }^{3}$ & $\mathrm{y}=246.68-18.81 \mathrm{x}_{1}-16.51 \mathrm{x}_{2}^{2}-13.82 \mathrm{x}_{1} \mathrm{x}_{2}$ & 0.032 & 0.87 & $0.07^{\mathrm{ns}}$ \\
\hline Setback w ${ }^{3}$ & $\mathrm{y}=71.01-14.54 \mathrm{x}_{1}-12.47 \mathrm{x}_{1}^{2}$ & 0.019 & 0.75 & $0.15^{\mathrm{ns}}$ \\
\hline$\Delta \mathrm{H}^{4}$ & $\mathrm{y}=4.08+1.36 \mathrm{x}_{1}-3.72 \mathrm{x}_{2}+1.52 \mathrm{x}_{2}^{2}$ & 0.033 & 0.93 & $0.32^{\mathrm{ns}}$ \\
\hline$\Delta \mathrm{H} \mathrm{w}^{4}$ & $\mathrm{y}=10.55-3.99 \mathrm{x}_{2}$ & 0.000 & 0.79 & $0.20^{\mathrm{ns}}$ \\
\hline Hardness $o^{5}$ & $\mathrm{y}=2.08-0.75 \mathrm{x}_{1}+0.66 \mathrm{x}_{1}^{2}-0.13 \mathrm{x}_{1} \mathrm{x}_{2}$ & 0.040 & 0.98 & $0.80^{\mathrm{ns}}$ \\
\hline Hardness $w^{5}$ & $\mathrm{y}=3.76-1.25 \mathrm{x}_{1}+0.90 \mathrm{x}_{1}^{2}$ & 0.006 & 0.86 & $0.63^{\text {ns }}$ \\
\hline Transparency o ${ }^{2}$ & $\mathrm{y}=0.81-0.13 \mathrm{x}_{1}+0.16 \mathrm{x}_{2}$ & 0.000 & 0.93 & $0.62^{\text {ns }}$ \\
\hline
\end{tabular}

ns: not significant; LF: Lack of Fit; * $\mathrm{p} \leq 0.05$; o: OSP starch; w:WSP starch; ${ }^{1} \mathrm{~g} \cdot \mathrm{g}^{-1} ;{ }^{2} \% ;{ }^{3} \mathrm{cP} ;{ }^{4} \mathrm{~J} / \mathrm{g} ;{ }^{5} \mathrm{~N}$. Source: Authors.

\subsection{Water solubility index (WSI) and water absorption index (WAI)}

The adjusted significant multiple regression models ( $\mathrm{p}<0.05)$ of theses parameters were: WAI at $70^{\circ} \mathrm{C}$ and WSI at 60 and $80^{\circ} \mathrm{C}$ (for OSP autoclaved starch), WAI at 60 and $70^{\circ} \mathrm{C}$ and WSI at $70^{\circ} \mathrm{C}$ (for WSP autoclaved starch) (Table 1).

For the OSP autoclaved starch WAI at $70^{\circ} \mathrm{C}$, only the linear and quadratic effects of the moisture content were significant and positive (Table 1), and the highest values $\left(12.0 \mathrm{~g} \mathrm{~g}^{-1}\right.$ ) were found for moisture contents above $37 \%$ (Figure $1 \mathrm{~A}$ ). 
Figure 1. A: WAI of OSP autoclaved starch at $70{ }^{\circ} \mathrm{C}$; B: WAI of WSP autoclaved starch at $60{ }^{\circ} \mathrm{C}$; C: WAI of WSP autoclaved starch at $70{ }^{\circ} \mathrm{C}$; D: WSI of OSP autoclaved starch at $60{ }^{\circ} \mathrm{C}$; E: WSI of OSP autoclaved starch at $80^{\circ} \mathrm{C}$; F: WSI of WSP autoclaved starch at $70{ }^{\circ} \mathrm{C}$.
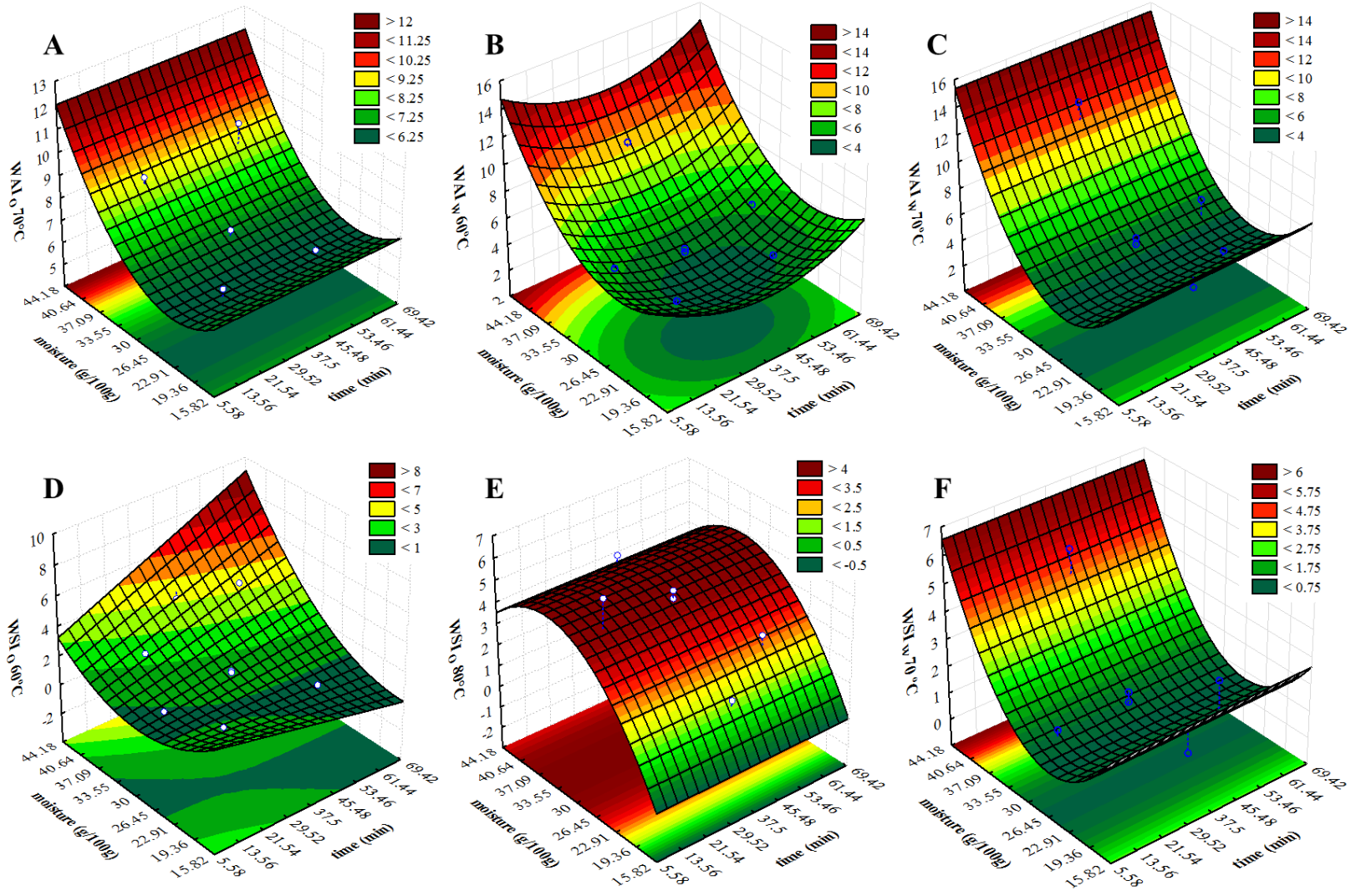

Source: Authors.

The WSP autoclaved starch WAI at $60^{\circ} \mathrm{C}$ was modified due to the positive linear effect for moisture and the positive quadratic effects of reaction time and moisture. The WSP autoclaved starch WAI at $70{ }^{\circ} \mathrm{C}$ was only changed by the positive linear and quadratic effects of moisture (Table 1). Higher WAI values for the WSP autoclaved starch at $60^{\circ} \mathrm{C}\left(14.8 \mathrm{~g} \mathrm{~g} \mathrm{~g}^{-1}\right)$ and at $70{ }^{\circ} \mathrm{C}\left(15.5 \mathrm{~g} \mathrm{~g}^{-1}\right)$ were observed with moisture contents above $40 \%$ (Figures $1 \mathrm{~B}$ and $1 \mathrm{C}$ ).

The OSP autoclaved starch WSI at $60^{\circ} \mathrm{C}$ fluctuated significantly with the positive linear effects of reaction time and moisture content, the positive quadratic effect of moisture content and the positive interaction effect of the independent variables (Table 1). The maximum water solubility (9.0\%) was found after exposure times greater than 57 min. and moisture contents above $43 \%$ (Figure 1D). The OSP autoclaved starch WSI at $80{ }^{\circ} \mathrm{C}$ was affected by the positive linear and negative quadratic effects of the moisture content and was not influenced by time (Table 1). The highest water solubilities (5.0\%) were determined at moisture contents above 30\% (Figure 1E). Also, for the WSP autoclaved starch WSI at $70{ }^{\circ} \mathrm{C}$, the linear and quadratic effects of the moisture content were positive (Table 1), reaching values greater than $6.5 \%$ with moisture contents above $40 \%$ (Figure 1F).

Previous studies with native starches obtained for WAI of WSP e WSI of OSP at $60{ }^{\circ} \mathrm{C}$ were lower $\left(6.7 \mathrm{~g} \mathrm{~g}^{-1}\right.$ and 1.0 $\%$, respectively) (Paixão e Silva et al., 2020) than the indexes found in this research for the same autoclaved starches (14.8 $\mathrm{g} g-$ ${ }^{1}$ and $9,0 \%$, respectively), indicating a tendency to increase theses indexes with the autoclave at this temperature of analysis. Increases in absorption and solubility were also obtained with autoclaved arrowroot starch (Fideles et al., 2019). 
The autoclave treatment associated with a test temperature caused greater changes in the starch granules, since it favored water entering the structure (Jyothi et al., 2010). However, the changes are not only caused by the treatment, but also by the analysis temperature (Bento et al., 2019), as can be seen by the reduction in solubility at $80{ }^{\circ} \mathrm{C}$ for the OSP autoclaved starch ( Figures 2D and 2E). Also, the pasting temperature of OSP native starch observed previously $\left(73.8^{\circ} \pm 0.5^{\circ} \mathrm{C}\right)($ Paixão e Silva et al., 2020) was lower than analysis temperature.

The increase in solubility and swelling power is due to the breakdown of hydrogen bonds between the starch granule molecules, which provides greater magnitude of the interaction between the amorphous and crystalline domains of the starch (Bello-Pérez, Sánchez-Rivera, Núñez-Santiago, Rodríguez-Ambriz, \& Román-Gutierrez, 2010). Thus, the increase in temperature weakens the intramolecular bonds in the starch, favoring the amylose leaching process, thus increasing solubility. Weaker forces, such as those of Vander Walls, relax and cause the granules to absorb water and swell, and, as a result, the lower molecular weight amylose dissolves and is released from the granule into the surrounding medium, thus increasing the starch solubility (Bento et al., 2020). The low hydration capacity of the amylopectin-rich fraction is due to the water penetration restrictions, thus limiting the swelling and solubility capacity of these portions (Jamir \& Kottapalli, 2017). Thus, the solubility and swelling power of the autoclaved starch granules are probably affected by the proportion of amylose and amylopectin in each starch, as well as by the arrangement between the amylose and amylopectin.

\subsection{Thermal properties}

The gelatinization temperatures determined from the DSC thermograms (Tonset, Tpeak and Tfinal) of the autoclaved starches were not significantly modified (Table 1), although the gelatinization enthalpy could be modelled (p<0.05).

The OSP autoclaved starch gelatinization enthalpy was reduced with increasing moisture content, while the exposure time and the quadratic effect of the moisture content increased the energy required for starch gelatinization (Table 1). The energy required for gelatinization was higher $\left(22.0 \mathrm{~J} . \mathrm{g}^{-1}\right)$ in the time below 13 and above 62 min. and with moisture contents below 19\% (Figure 2A). For WSP autoclaved starch, only an increase in moisture content reduced the energy required to gelatinize the granules (Table 1), and the energy required for gelatinization was higher $\left(18.0 \mathrm{~J}\right.$. $\left.\mathrm{g}^{-1}\right)$ with moisture contents below 19\% (Figure 2B). These optimized values for the autoclaved starches are higher than the preliminary studies with natives WSP and OSP starches that found enthalpy of gelatinization of 13.5 and $11.24 \mathrm{~J} . \mathrm{g}^{-1}$, respectively (Paixão e Silva et al., 2020). 
Figure 2. A: Gelatinization enthalpy of OSP autoclaved starch; B: Gelatinization enthalpy of WSP autoclaved starch; C: final viscosity of OSP autoclaved starch; D: breakdown of OSP autoclaved starch; E: Setback of WSP autoclaved starch;
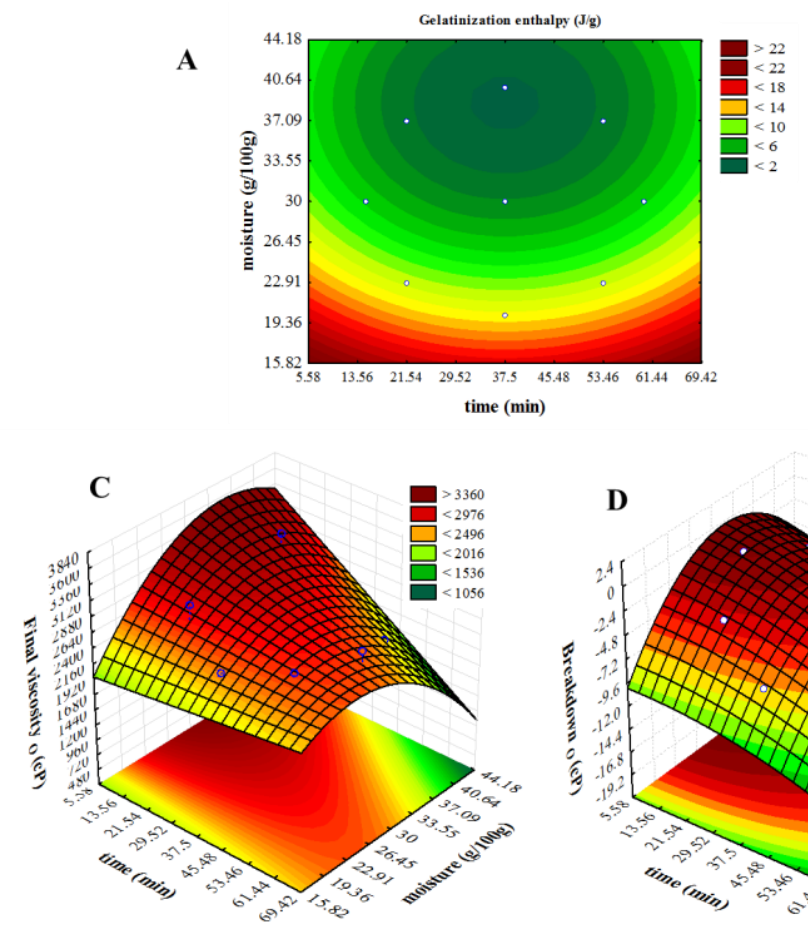

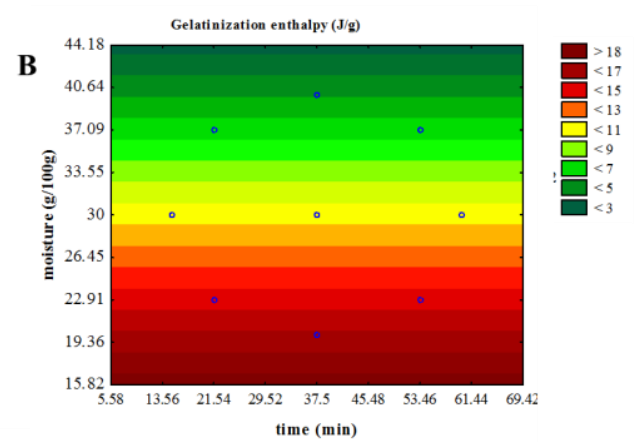

time (min)

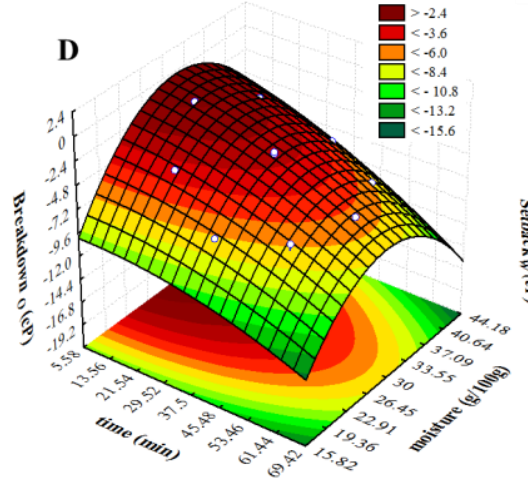

Source: Authors.

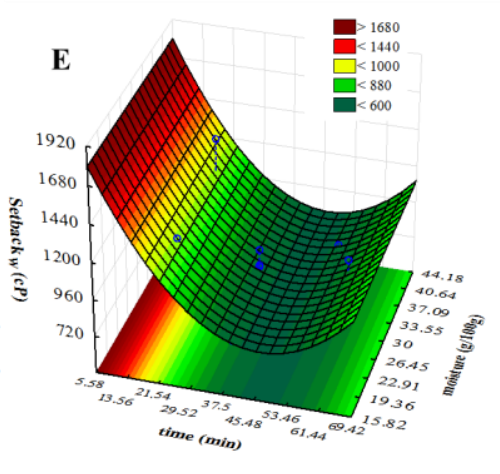

\subsection{Pasting properties}

Regarding the pasting properties, only the models for the breakdown and final viscosities of OSP autoclaved starch were significant $(\mathrm{p} \leq 0.05)$; and that for setback for WSP autoclaved starch (Table 1).

The OSP autoclaved starch breakdown fluctuated significantly due to the negative linear and quadratic effects for the reaction time, positive linear and negative quadratic effects for the moisture content and for the time and moisture content interaction. There were also significant negative linear effects of the reaction time, quadratic moisture and the interaction between time and moisture content for the final viscosity of this starch (Table 1).

The OSP autoclaved starch models showed maximum points (final viscosity $3600 \mathrm{cP}$ and breakdown $0 \mathrm{cP}$ ) with milder treatments: times shorter than 21 min and moisture contents of 26 to 40\% (Figures 2C and 2D). OSP native starch showed a value of $2334 \pm 9 \mathrm{cP}$ for the final viscosity and $1596 \pm 18 \mathrm{cP}$ for the breakdown (Paixão e Silva et al., 2020). The increase in the final viscosity of autoclaved sweet potato starches is in agreement with the results found for water absorption, which increased due to the autoclave treatment, which makes the gel more viscous. X. Li et al. (2020) using an autoclave at $121^{\circ} \mathrm{C}$ for 20 minutes in ginger starch also observed an increase in the final viscosity and a reduction in the breakdown of the paste. This can be due the autoclaving breaks down the granular structure of the starch producing solubilized structures and non-solubilized fractions of amylose and/or amylopectin in the form of gelatinized starch (Agama-Acevedo, Pacheco-Vargas, Bello-Pérez, \& Alvarez-Ramirez, 2018; Chung, Liu, \& Hoover, 2009).

The WSP autoclaved starch setback model demonstrated negative linear and quadratic effects with time. The maximum value $(1800 \mathrm{cP})$ was determined with times of less than $7 \mathrm{~min}$., but the moisture content was not significant (Figure 2E); while the native starch presented a setback of $580 \mathrm{cP}$ (Paixão \& Silva et al., 2020). Similarly, an increase of the autoclaved cassava starch setback viscosity under similar conditions was also observed (Abraham, 1993). 


\subsection{Gel hardness and transparency}

The hardness of the OSP autoclaved starch gel was significantly affected by the linear component of time and by the interaction of time and moisture content, which contributed to a reduction in strength of the modified starch gel. However, the quadratic component of time increased the strength of the gel, as shown in Figure 3A. The maximum gel hardness values of this starch $(6.5 \mathrm{~N})$ were obtained in less than $7 \mathrm{~min}$. For the hardness of the WSP autoclaved starch gel, only the linear time component contributed to a reduction in strength of the modified starch gel, and its quadratic component increased the gel strength, as shown in Figure 3B. The maximum hardness values $(10.0 \mathrm{~N})$ were also determined in less than 7 min. Thus, the maximum gel hardness of the WSP autoclaved starch $(10 \mathrm{~N})$ was greater than that of the OSP autoclaved starch $(6.5 \mathrm{~N})$. This can be explained because the gelatinization temperature of the WSP starch $\left(76.55^{\circ} \mathrm{C}\right)$ was higher than that of the OSP starch $\left(74.35^{\circ} \mathrm{C}\right.$ ); and in addition, the gel hardness of these native starches were $8.16 \mathrm{~N}$ (WSP starch) and $3.69 \mathrm{~N}$ (OSP starch) (Paixão e Silva et al., 2020), indicating that the autoclave treatment increased the gel strength.

Figure 3. A: Gel hardness of OSP autoclaved starch; B: Gel hardness gel of WSP autoclaved starch; C: Transmittance gel of OSP autoclaved starch.
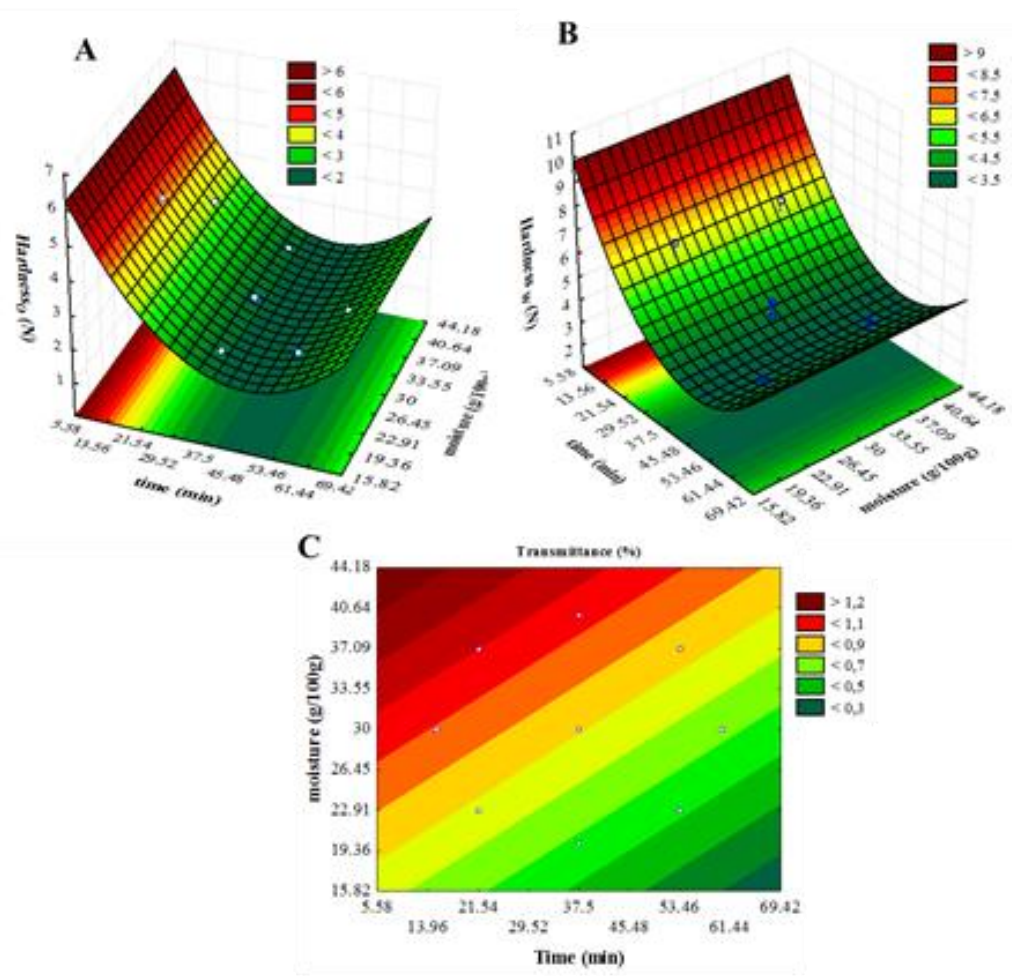

Source: Authors.

The transparency of OSP autoclaved starch was positively influenced by the moisture content used in the modification and negatively influenced by the starch exposure time (Table 1$)$. The highest value $(1.2 \%)$ was determined with the highest moisture (above $40 \%$ ) content and the shortest exposure time (less than $13 \mathrm{~min}$.) (Figure 3C).

The transparency of this native starch was $4.6 \%$ (Paixão \& Silva et al., 2020) higher than the autoclaved one, indicating that the method reduces the transparency of the gel due to degradation of the starch chains (Ashwar et al., 2016). The paste translucency also decreased for autoclaved cassava starch by Abraham (1993). 


\subsection{SEM}

The granules of native sweet potato starches have a polygonal, spherical and semi-spherical shape, with varying sizes, smooth surfaces, without holes or cracks (Paixão e Silva et al., 2020; Wang et al., 2020). The micrographs showed that the shapes and sizes were similar to natives one, however the autoclave process promoted the appearance of scratches, cracks, and depressions, also seen by Babu and Parimalavalli (2013); H. Li et al. (2020) with modification of sweet potato and ginger starches. The treatments with $30 \%$ and $20 \%$ of moisture at $37,5 \mathrm{~min}$. were the ones that showed the greatest change int the surface of granules (Figures 4 A, 4B, 4C and 4D).

Figure 4. SEM (with magnifications of 1500x) of (A) WSP autoclaved starch at 37.5 minutes and $20 \%$ moisture; (B) WSP autoclaved starch at 37.5 minutes and $30 \%$ moisture; (C) OSP autoclaved starch at 37.5 minutes and $20 \%$ moisture; and (D) OSP autoclaved starch at 37.5 minutes and $30 \%$ moisture;
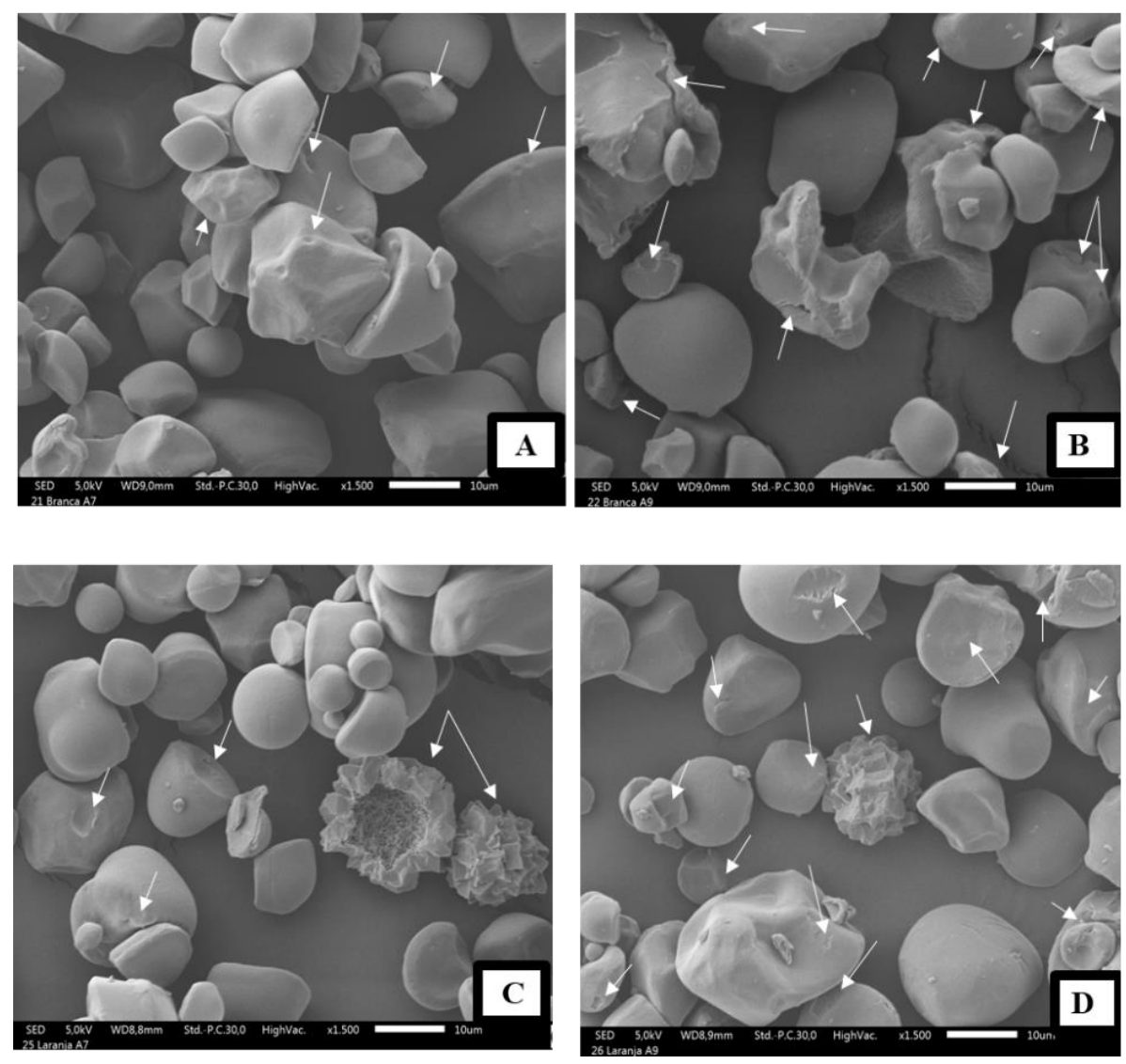

Source: Authors.

Additionally, it was possible to observe the presence of pre-gelatinized granules in the OSP autoclaved starch (Figures 4C and 4D), confirming that the autoclave promotes the break of granular structure, as mentioned in RVA results. Deka and Sit (2016) in their studies using an autoclave to modify taro starch reported that a loss of physical integrity this might be attributed to the partial gelatinization of the starch during the heat moisture treatments as evidenced by swelling, breakup, and/or aggregation/fusion of the granules.

\section{Conclusion}

The physical modification by an autoclave proved to be advantageous for modify the analyzed starches. The maximum values of the response surfaces (of the models that were significant) showed an increase of WAI at $60^{\circ} \mathrm{C}$ of WSP starch and of WSI at $60^{\circ} \mathrm{C}$ of OSP starch; an increase of final viscosity of OSP starch; an increase of setback of WSP starch; an 
increase of gelatinization enthalpy for both starches; and a reduction of breakdown of OSP starch. Besides that, micrographs showed degradation and pre-gelatinization of the granules.

Therefore, due the promising use the authors suggest future researches with WSP and OSP autoclaved starches to test the technological applications in foods.

\section{Acknowledgments}

The authors wish to thank FAPEG (Goiás State Research Support Foundation) for the financial support, and the Federal University of Goiás for their support in carrying out the analyses.

\section{References}

Abraham, T. E. (1993). Stabilization of Paste Viscosity of Cassava Starch by Heat Moisture Treatment. 45(4), 131-135. 10.1002/star.19930450404

Agama-Acevedo, E., Pacheco-Vargas, G., Bello-Pérez, L. A., \& Alvarez-Ramirez, J. (2018). Effect of drying method and hydrothermal treatment of pregelatinized Hylon VII starch on resistant starch content. Food Hydrocolloids, 77, 817-824. https://doi.org/10.1016/j.foodhyd.2017.11.025

Akanbi, C. T., Kadiri, O., \& Gbadamosi, S. O. (2019). Kinetics of starch digestion in native and modified sweetpotato starches from an orange fleshed cultivar. International Journal of Biological Macromolecules, 134, 946-953. https://doi.org/10.1016/j.ijbiomac.2019.05.035

Ashwar, B. A., Gani, A., Wani, I. A., Shah, A., Masoodi, F. A., \& Saxena, D. C. (2016). Production of resistant starch from rice by dual autoclavingretrogradation treatment: Invitro digestibility, thermal and structural characterization. Food Hydrocolloids, 2016 56, 108-117. 10.1016/j.foodhyd.2015.12.004

Astuti, R. M., Widaningrum, Asiah, N., Setyowati, A., \& Fitriawati, R. (2018). Effect of physical modification on granule morphology, pasting behavior, and functional properties of arrowroot (Marantha arundinacea L) starch. Food Hydrocolloids, 81, 23-30. https://doi.org/10.1016/j.foodhyd.2018.02.029

Babu, A. S., \& Parimalavalli, R. (2013). Effect of Autoclaving on Functional, Chemical, Pasting and Morphological Properties of Sweet Potato Starch. Journal of Root Crops, 39(1), 78-83.

Babu, A. S., \& Parimalavalli, R. (2014). Effect of Autoclaving on Functional, Chemical, Pasting and Morphological Properties of. Journal of Root Crops, $39(1), 78-83$.

Bello-Pérez, L. A., Sánchez-Rivera, M. M., Núñez-Santiago, C., Rodríguez-Ambriz, S. L., \& Román-Gutierrez, A. D. (2010). Effect of the pearled in the isolation and the morphological, physicochemical and rheological characteristics of barley starch. Carbohydr. Polym., 81(1), 63-69. https://doi.org/10.1016/j.carbpol.2010.01.056

Bento, J. A. C., Ferreira, K. C., de Oliveira, A. L. M., Lião, L. M., Caliari, M., \& Júnior, M. S. S. (2019). Extraction, characterization and technological properties of white garland-lily starch. International Journal of Biological Macromolecules, 135, 422-428. https://doi.org/10.1016/j.ijbiomac.2019.05.141

Bento, J. A. C., Fidelis, M. C., de Souza Neto, M. A., Lião, L. M., Caliari, M., \& Soares Júnior, M. S. (2020). Physicochemical, structural, and thermal properties of "batata-de-teiú” starch. International Journal of Biological Macromolecules, 145, 332-340. https://doi.org/10.1016/j.ijbiomac.2019.12.208

Carballo Pérez, I., Mu, T.-H., Zhang, M., \& Ji, L.-L. (2018). Effect of high hydrostatic pressure to sweet potato flour on dough properties and characteristics of sweet potato-wheat bread. International Journal of Food Science \& Technology, 53(4), 1087-1094. 10.1111/ijfs.13687

Chung, H.-J., Liu, Q., \& Hoover, R. (2009). Impact of annealing and heat-moisture treatment on rapidly digestible, slowly digestible and resistant starch levels in native and gelatinized corn, pea and lentil starches. Carbohydrate polymers, 75(3), 436-447. https://doi.org/10.1016/j.carbpol.2008.08.006

Deka, D., \& Sit, N. (2016). Dual modification of taro starch by microwave and other heat moisture treatments. International Journal of Biological 
Fideles, M. C., Bento, J. A. C., Ferreira, K. C., de Oliveira, A. L. M., Caliari, M., \& Soares, M. S., Jr. (2019). Physicochemical and technological characteristics of arrowroot flour modified by ultrasound and low-temperature heat treatment/Caracteristicas fisico-quimicas e tecnologicas da farinha de araruta modificada por ultrassom e por tratamento termico de baixa umidade. Ciência Rural, 49, NA.

Guo, J., Liu, L., Lian, X., Li, L., \& Wu, H. (2014). The properties of different cultivars of Jinhai sweet potato starches in China. International Journal of Biological Macromolecules, 67, 1-6. https://doi.org/10.1016/j.ijbiomac.2014.03.002

Huang, T.-T., Zhou, D.-N., Jin, Z.-Y., Xu, X.-M., \& Chen, H.-Q. (2016). Effect of repeated heat-moisture treatments on digestibility, physicochemical and structural properties of sweet potato starch. Food Hydrocolloids, 54, 202-210. https://doi.org/10.1016/j.foodhyd.2015.10.002

Jamir, K., \& Kottapalli, S. (2017). Isolation, characterization and comparative study of starches from selected Zingiberaceae species, a non-conventional source. Food Hydrocoll., 72. https://doi.org/10.1016/j.foodhyd.2017.06.004

Jyothi, A. N., Sajeev, M. S., \& Sreekumar, J. N. (2010). Hydrothermal Modifications of Tropical Tuber Starches. 1. Effect of Heat-Moisture Treatment on the Physicochemical, Rheological and Gelatinization Characteristics. Starch - Stärke, 62(1), 28-40. 10.1002/star.200900191

Lee, B. H., \& Lee, Y. T. (2017). Physicochemical and structural properties of different colored sweet potato starches. Starch-Stärke, 69(3-4), 1600001. $10.1002 /$ star.201600001

Li, H., Gui, Y., Li, J., Zhu, Y., Cui, B., \& Guo, L. (2020). Modification of rice starch using a combination of autoclaving and triple enzyme treatment: Structural, physicochemical and digestibility properties. International Journal of Biological Macromolecules, 144, 500-508. https://doi.org/10.1016/j.ijbiomac.2019.12.112

Li, H., Yu, L., Yu, W., Li, H., \& Gilbert, R. (2019). Autoclaved rice: The textural property and its relation to starch leaching and the molecular structure of leached starch. Food chemistry, 283, 199-205. https://doi.org/10.1016/j.foodchem.2019.01.030

Li, X., Chen, W., Chang, Q., Zhang, Y., Zheng, B., \& Zeng, H. (2020). Structural and physicochemical properties of ginger (Rhizoma curcumae longae) starch and resistant starch: A comparative study. International Journal of Biological Macromolecules, 144, 67-75. https://doi.org/10.1016/j.ijbiomac.2019.12.047

Narpinder, S., Amritpal, K., Khetan, S., \& Rajarathnam, E. (2013). Potato: production, composition and starch processing. In (pp. 23-48). Beverly: Scrivener Publishing LLC.

Paixão e Silva, G. d. L., Bento, J. A. C., Ribeiro, G. O., Lião, L. M., Soares Júnior, M. S., \& Caliari, M. (2020). Application potential and technological properties of colored sweet potato starches. Starch - Stärke, in press. 10.1002/star.202000100

Pereira, A. S., Shitsuka, D., Parreira, F., \& Shitsuka, R. (2018). Metodologia da pesquisa científica.[e-book].

Schneider, C. A., Rasband, W. S., \& Eliceiri, K. W. (2012). NIH Image to ImageJ: 25 years of image analysis. Nature methods, 9(7), 671.

Shah, A., Masoodi, F. A., Gani, A., \& Ashwar, B. A. (2016). In-vitro digestibility, rheology, structure, and functionality of RS3 from oat starch. Food chemistry, 212, 749-758. https://doi.org/10.1016/j.foodchem.2016.06.019

Song, M.-R., Choi, S.-H., Kim, H.-S., Kim, B.-Y., \& Baik, M.-Y. (2015). Efficiency of High Hydrostatic Pressure in Preparing Amorphous Granular Starches. Starch - Stärke, 67. 10.1002/star.201500002

Trung, P. T. B., Ngoc, L. B. B., Hoa, P. N., Tien, N. N. T., \& Hung, P. V. (2017). Impact of heat-moisture and annealing treatments on physicochemical properties and digestibility of starches from different colored sweet potato varieties. International Journal of Biological Macromolecules, 105, 1071-1078. https://doi.org/10.1016/j.ijbiomac.2017.07.131

Wang, H., Yang, Q., Gao, L., Gong, X., Qu, Y., \& Feng, B. (2020). Functional and physicochemical properties of flours and starches from different tuber crops. International Journal of Biological Macromolecules, 148, 324-332. https://doi.org/10.1016/j.ijbiomac.2020.01.146 
Research, Society and Development, v. 10, n. 1, e14210111620, 2021

(CC BY 4.0) | ISSN 2525-3409 | DOI: http://dx.doi.org/10.33448/rsd-v10i1.11620

Wani, I. A., Sogi, D. S., Wani, A. A., Gill, B. S., \& Shivhare, U. S. (2010). Physico-chemical properties of starches from Indian kidney bean (Phaseolus vulgaris) cultivars. International Journal of Food Science \& Technology, 45(10), 2176-2185. 10.1111/j.1365-2621.2010.02379.x

Zavareze, E. d. R., \& Dias, A. R. G. (2011). Impact of heat-moisture treatment and annealing in starches: A review. Carbohydrate polymers, 83(2), 317-328. https://doi.org/10.1016/j.carbpol.2010.08.064

Zheng, J., Li, Q., Hu, A., Yang, L., Lu, J., Zhang, X., \& Lin, Q. (2013). Dual-frequency ultrasound effect on structure and properties of sweet potato starch. Starch-Stärke, 65(7-8), 621-627. 10.1002/star.201200197

Zhu, F. (2015). Impact of ultrasound on structure, physicochemical properties, modifications, and applications of starch. Trends in Food Science \& Technology, 43(1), 1-17. https://doi.org/10.1016/j.tifs.2014.12.008

Zuo, Y. Y. J., Hébraud, P., Hemar, Y., \& Ashokkumar, M. (2012). Quantification of high-power ultrasound induced damage on potato starch granules using light microscopy. Ultrasonics Sonochemistry, 19(3), 421-426. https://doi.org/10.1016/j.ultsonch.2011.08.006 